\title{
Strategic Fit Issues in Information System Research: Concept, Operationalization and Future Directions
}

\author{
Zhiqiang Wang* \\ School of Business Administration, \\ South China University of Technology, Guangzhou, China
}

Tel: $86-20-87112682$

bmzqwang@scut.edu.cn

\begin{abstract}
In recent years, strategic fit issues attract both academia and practitioners due to the debate of productivity paradox of information system (1). $*$ This study provides a comprehensive literature review on the strategic fit issues in IS research and suggest some future research directions. In detail, conceptualization of strategio fit in IS research, operationalization of related constructs, and anteceden s and consequences of strategic fit are included. The main contribution of this studris to explicitly and critically investigate the current status of strategic fit research in IS area. TheoreticaDbackground of fit studies in strategic management is also reviewed to explore theoretical and methodological support in future research.
\end{abstract}

Keywords: strategic fit, information system, literature review

\section{Introduction}

Plethora of studies have been conducted to investigate what is widely known as the productivity paradox in IS (information system) research. The words firstly appeared in a provocative study, "Anerica's Technology Dilemma: A Profile of the Information Economy" by Morgan Stanley's chief economist Steven Roach published in Morgan Stanley's April 22, 1987 economios newsletter series. In the firm level, things happened like that some organizations have spent great investment on IT with little benefit, while others have spent similar amounts of money with great success.

The relationship between information technology and productivity is widely discussed but only little agreement is achieved (Ward, 2012). Several explanations have been provided for the productivity paradox. One of the explanations is from the methodological view (Brynjolfsson, 1993). Mainly four reasons are referred to in his review, which are mismeasurement of outputs and inputs, lags due to learning and adjustment, redistribution and dissipation of profits and mismanagement of information and technology. He even felt disappointed of researches on IT and productivity for the reason of ultimate value of billions of dollars of IT investment and measures and methods commonly used for productivity assessment. Some organizational studies offer another explanation, which focused on the factors that mediate the relationship between IT use and firm profitability in a resource-based

\footnotetext{
* Corresponding author

This research is supported by the Guangdong Provincial Soft Science Research Program (\#2011B070400005) and the Fundamental Research Funds for the Central Universities (\#x2gsD2118490).
} 
view (Bharadwaj, 2000; Ravichandran and Lertwongsatien, 2005).

Another kind of explanation is dependent on contingency theory. Contingency theory generally proposes a conditional association of two or more independent variables with a dependent outcome and empirically tests it (Drazin and Van de Ven, 1985). The dominant mode of inquiry of contingency research is reductionistic analysis, which separately analyzes a social entity's constituent parts to understand its behavior (Meyer et al., 1993). Organizational theorists and strategic management researchers believe that firms would perform well if fit is realized internally and externally (Miller, 1992). In this point of view, contingency theory is believed to provide a valuable theoretical basis for investigating the relationship between IT and firm performance (Iivari, 1992). The underlying assumption for this explanation is that IT actually impacts on firm performance, but the effect is dependent upon aligning the firm's management of IT from the perspective of its strategy, its structure and its environment (Merali et al., 2012). As stated in Brynjolfsson and Hitt (1998), the greatest benefits of IT seemed to be realized when IT investment is coupled with other complementary investment, and strategies, new business processes and new organ zations all seemed to be important in realizing the maximum benefit of IT Therefore, alignment issues in information system research attract great interest (Aversano et gl., 2012).

The purpose of this study is to conduct a comprehensive literature review on the strategic fit issues in IS research and suggest some future research directions. In detail, the conceptualization of fit or alignment used in the IS strategic fit research are reviewed firstly. Then investigation of different constructs used in past studies is conducted to demonstrate the research framework of strategic fit research. Strategic alignmen models are discussed in this part too. Thirdly, the factors that influence the alignment are detected. Fourthly, alignment gains or consequents usually used in pastesearch are summarized. Lastly, conclusions are made based on the literature review and future research directions are suggested.

The main contribution of this review is to explicitly and critically investigate the current status of strategic fit research in IS area. Theoretical background of fit studies in strategic management is also revieved to explore theoretical and methodological support in future research. The review could provide some meaningful ideas and viable ways for future studies.

In this research, strategic fit mainly refers to the alignment among business strategy, IS related strategy, and IT structure. The boundary of this study is limited to the conceptualization of fit in IS research, research framework, antecedents and consequence of strategic fit. th is showed in Figure 1.

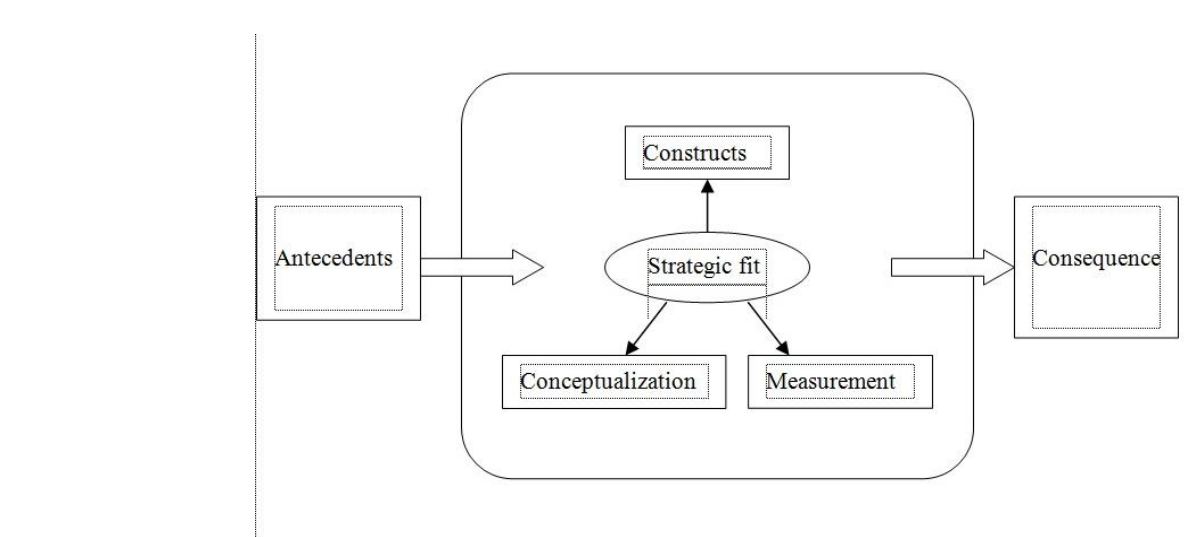

Figure 1 


\section{Conceptualization of Fit in IS Research}

\subsection{Theoretical and methodological background}

Contingency relationships were emphasized by strategic management researchers and organization theorists for a long time. An early contingent research by Hayes and Wheelwright (1979) proposed that superior manufacturing performance is contingent on the degree of alignment between the process environment and the volume variety characteristics of the market. The issue of environment fit and internal fit has been emphasized for long time based on contingency theory (Lawrence and Lorsch, 1967; Miller, 1992; Skinner, 1974; Hill and DukeWoolley, 1983; Schmenner, 1983). Miller (1992) referred to environment fit as the match of structures and processes to environment, while internal fit as the complementarities of structures and process based on the prior works. Skinner (1969) stated that the companies need external fit when they were developing and implementing manufacturing strategy. Similarly, internal fit was another research focus by many scholars as the complementary between organizations' structures and processes (Skinner, 1974, Schmenner, 1983, Hayes and Wheelwright, 1984).

Fit as a core concept of Structural Contingency Theory has been defined and operationalized from different perspectives. In Venkatraman's (1989) review work, the author identified six perspectives of strategic fit: fit as moderation, fit as mediation, fit as matching, fit as covariation, fit as profile deviation and fit as gestalts. Each type of fit suggests different relationships among variables and was modeled with different methodologies. The perspective of fit as moderation is conceptualized as the interaction between two variables. The proper analysis technique is ANOVA Or moderated regression analysis. The perspective of fit as mediation is conceptualized in the way that an intervening variable exists between several antecedent variables and the consequent variable. The appropriate analysis for this perspective is path analysis. Fin as matching is defined as the match between two variables. The analysis technique for this fit is deviation score analysis, residual analysis or ANOVA. Fit as covariation is defined anternal consistency among a set of underlying theoretically related variables. Second-order factor analysis is a proper technique for testing the hypothesis. Fit as profile deviation is defined in system view and as the internal consistency with multiple contingencies. Correlation is used to test the relationship between the distance from the ideal profile and performance. Fit as gestalt is defined as the pattern of a set of variables. Cluster analysis is often usec to test the hypothesis for this perspective with strong theoretical support.

Venkatraman's (1989) seminal work provides a viable way to conceptualize fit and test relationship between fit and performance. Many later works in Strategic Management and Operations Management stream have investigated the fit issues with the six perspectives (Venkatraman and Prescott, 1990; Das and Narasimhan, 2001; Devaraj et al., 2004; Silveira, 2005). It is interesting to see how these six perspectives are applied in the IS strategic fit research.

\subsection{Fit conceptualization in IS research}

Some of the strategic fit studies in IS stream followed one of the six perspectives. Adopting a conceptualization of fit as gestalts, Bergeron et al. (2004) examined the impact of coalignment among business strategy, business structure, IT strategy, and IT structure on business performance in 110 small and medium-size companies. The study validated that a conflictual coalignment pattern of business strategy, business structure, IT strategy, and IT structure would undermine the firm's competence in profit. Six alignment types are formed 
based on the bivariate relationship among four alignment domains, which are business strategy, business structure, IT strategy, and IT structure. Only four clustering variables of business strategy, business structure, IT strategy, and IT structure were used in the Ward's hierarchical cluster analysis. The unidimensional characteristic of the four constructs' measurement could only offer a limited alignment study in IS research. Actually, each construct is measured as the average of several dimensions. It would be more interesting if the study could investigate the complementary effect by the gestalt of these sub-constructs.

Similar to Venkatraman's (1989) fit as profile deviation, Sabherwal and Chan (2001) conceptualized the alignment between business strategy and IS strategy. Based on the theory, the study operationalized the high, medium values for ideal profile of business strategy and IS strategy as $+1,-1$ and 0 respectively. It would be more reasonable if the ideal profile is formed by the high performance firms as in Venkatraman and Prescott (1990). A system view of the alignment between business strategy and IS strategy is adopted in this stody for the multi-dimentional measurement of the two constructs. A recent research by Chan et al. (2006) also use the approach employed by Sabherwal and Chan (2001).

Palmer and Markus (2000) defined strategic alignment as correlation between business strategy of the firm and the firm's IT strategy. They claimed that they used the fit as moderation in Venkatraman's (1989) conceptualizations However, operationalization and data analysis method of fit as matching are used instead of fit as moderation. The study matched the business strategy of retailer pipeline and dimensions of IT strategy. Business strategy focusing on supplier, internal, and customer mached IT strategy for supplier participating, transaction efficiency and custome detail respectively. This measurement might not capture the effect of alignment of business strategy and IT strategy in the firms that have a comparable focus on the dimensions of these strategy So it may be seen as the explanation of why no relationship was found between the alignment and business performance.

Theory-based ideal alignment patterns are formed by matching between dimensions of business strategy, business structure, IS strategy, and IS structure to investigate dynamics of alignment in the firms (Sabnerwal et al 2001). The measurement may be useful in a case study but not meaningfulin the large sample empirical study because alignment patterns from past literature may not apply to all the firms.

Other studies in IS allignment esearch did not use any perspectives of fit that established by Venkatraman (1989). For example, Teo and King (1996) measured alignment between business planning and IS planling directly, which they named as the integration between business planning and IS planning. They stated that there were four stages taxonomy of BP-ISP integration that represents the extent of integration. The four stage taxonomy is separate planning with administrative integration, one-way linked planning with sequential integration, two-way linked planning with reciprocal integration, and integrated planning with full integration. In a sense, they only measured the method of IS strategy formation but not how well he IS strategy fit the business strategy.

As one of the key factors for successful IS planning, alignment between IS strategy and business-strategy is measured directly using 8 items (Segars and Grover, 1998). Although this method may be a good attempt to measure fit, it is difficult for the researchers to find an appropriate respondents to answer questions for measurement. Business strategy is decided by the top management and IS strategy is decided by IT managers. Either of them may have bias view on how well business strategy are aligned with IS strategy. 


\section{Framework of strategic fit research}

\subsection{Identification of relationships and constructs}

In IS strategic fit research, different constructs related to business and IS strategies are included in past studies (Chen et al., 2008; Sen and Sinha, 2011). For example, Chan et al., (1997) observed significant relationships between business orientations, IS strategy, IS effectiveness and business performance. Whereas Sabherwal and Kirs (1994) found that alignment between organizational success factors and IT capability facilitates organizational performance. Some researchers created a strategic alignment model as a framework to investigate the alignment issues in IS area.

The alignment between business strategy and IS strategy was investigated by Sabherwal and Chan (2001). They used the established typology of business strategy by Miles and Snow (1978), including Defenders, Analyzers, and Prospectors. Through a clear identification of IT, IS, and IM strategy, the study focused on the IS strategy, which concerns aligning systems or business applications of IT with business need to achieve strategic benefits. Their results showed that alignment between business strategy and IS strategy would influence overall business success in Prospectors and Analyzers but not in Defenders. Only four industries of banking, insurance, pharmaceutical manufacturing and auto-parts manufacturing were included in the sample which may influence the generalizability of theresults.

In the study of Tavakolian (1989), 52 large Organizations in the computer components industry were selected as sample to examine the relationship between information technology structure and organizational competitive strakegy. The results showed that there were significant relationship between information technology structure and competitive strategy. Their findings also supported that the fit between information technology structure and overall organizational context varables, including competitive strategy, would lead to successful implementation of information technology systems.

Henderson and Venkatraman (1993) suggested a model named strategic alignment model which is defined in terms of four fundamental domains of strategic choice: business strategy, information technology strategy, organizational infrastructure and processes, and information technology infrastructure and processes, In the dynamic alignment research, Sabherwal et al. (2001) also adopted the four domains of strategy as the framework of strategic alignment research.

Ho (1996) offered a strategic alignment model to investigate the alignment between manufacturing strategy and IT strategy. Through the implementation of MRP and JIT, the author examined the cross-domain alignment via strategic fit and functional integration in the strategic alignment model.

Avison et $d l$. , (2004) reported the use of strategic alignment model in a financial services firm. The study investigated alignment at the project level. Fifty five finished project that deployed by the IT department were use in the SAM to validate the alignment issues. Their resalts showed that SAM is useful as a management tool to create, assess and sustain strategic alignment between information technology and the business. Their research also indicated that IS planning was a mechanism to achieve the alignment.

\subsection{Measurement of constructs}

Different conceptualizations of these constructs are used for the different objectives of the researchers. The deficiency of clear distinction between different IS related strategies and consistent conceptualization of these strategies may hinder the progress of IS strategic fit research. The summary of IS related strategies is listed in Table 1 of Appendix. 
IS strategy is measured by examining the ways in which IS was being sought to impact the organizations. Six IS strategies are used, low cost, differentiation, growth, alliance, innovation and nonstrategic (Sabherwal et al., 2001). Whereas Sabherwal and Chan (2001) considered three dimension of IS strategy, which are IS for efficiency, IS for flexibility, IS for comprehensiveness. The three dimensions are measured in terms of four IS strategy attributes of operational support systems, market information systems, strategic decision support systems, and interorganizational systems. The same measurement of IS strategy were also used in Chan et al. (2006). From a system use point of view, Palmer and Markus (2000) described that IS strategy focused on supplier partnering, transaction efficiency and customer detail.

IT strategy can be seen as a four dimensional construct, which include competencies, role of IT, systems design and development, and infrastructure (Das et al., 1991) These dimensions are content dimensions of IT strategy. Their study investigated the content and process issues of strategic MIS planning. In Ho (1996), IT strategy was conceptralized in terms of structure and infrastructure. The structure of IT strategy include system competences, technology scope and IT alliance. The infrastructure of IT strategy includes IT architecture, processes, and skills. Apparently, Bergeron et al., (2004) agreed yith Das etal., (1991) on the dimensions of IT strategy. The IT strategy construct used in their study includes IT environment scanning and strategic use of IT. The first one reflects the firm's capability to detect and response to technological changes relative to competitors. The second one shows the benefits from IT use on firm's quality, competitiveness, and performance. Henderson and Venkatraman (1993) stated that IT strategy should be described in terms of external domain and internal domain. The IT strategy of external domain involved information technology scope, systemic competencies, and IT governance And the IT strategy of internal domain is comprised by IS architecture, IS processes, and IS skills.

IT structure has three dimensions of IT organizational architecture, technological architecture, and process and skill (Bergeron et al., 2004). They used IT planning and control and IT acquisition and imprementation Chen et al., (1997) conceptualized IS structure as centralized, decentralized, shared management of IS. In an early study of Tavakolian (1989), only centralized and decentralized IT structures were considered.

Earl (1989) clarified the differences between IS strategy, IT strategy, IM strategy. The author believed that IS strategy focuses on systems or business applications of IT, IT strategy is concerned nainly with teclonology policies, and IM strategy is related to the structures and roles for the management of IS and IT.

Business strategy is assessed by typology of Defenders, Analyzers and Prospectors (Das et al., 1991; Sabherwal and Chan, 2001). This Miles and Snow's (1978) typology provides a theoretical base for future empirical assessment of alignment between business strategy and IS strategy (Chan et al.,, 2006). It is perhaps the most commonly used and the best understood in IS research. Chen et al., (1997) focus on the business strategic orientation along dimensions of aggressiveness, analysis, defensiveness, futurity, proactiveness, risk aversion, and innovativeness. In another study by Bergeron et al., (2004), similar dimensions of business strategy are used except innovativeness.

\section{Factors that Influence Alignment}

In Sabherwal and Chan's (2001) research, the authors called for a study on the examination of cause or antecedents of alignment, which would be meaningful for the academics and practitioners. Not so many studies focus on this issue. The summary of research on antecedents of strategic fit is listed in Table 2 of Appendix. 
In the study of critical success factors in the alignment of IS plans with business plans, the results showed that top management commitment to the strategic use of IT, IS management knowledge about business, and top management confidence in the IS department are the top three factors (Teo and Ang, 1999). The alignment used in their research emphasized on content linkage rather than personnel or timing linkages.

Luftman et al., (1999) have conducted a research to find the enablers and inhibitors of business-IT alignment. Six enablers were identified as the activities to assist in the achievement of alignment of IT plans with business plans. These enablers of alignment are senior executive support for IT, IT's involvement in strategy development, IT's understanding the business, business-IT partnership, well-prioritized IT projects, and IT's demonstration of leadership.

Reich and Benbasat (2000) found four factors that influence the social dimension of alignment between business strategy and IT objectives. So the four factors that are shared domain knowledge between business and IT executives, IT implementation success, communication between business and IT executives, and connections between business and IT planning processes may be future investigated factors, which have impact on the alignment between business and IT strategy. The social dimension of alignment between business strategy and IT objectives emphasize that both business and IS planners should understand each other's objectives and plans (Reich and Benbasat, 1996).

Chan et al., (2006) developed and tested a model relating alignment, its antecedents, and its consequences. In their paper, five antecedents were tested in a SEM model. The five antecedents are shared domain knowledge, planning sophistication, prior IS success, organizational size, and environmental uncertainty. In the end, only direct effect of shared domain knowledge, prior IS success, organizational size, and environmental uncertainty were found in the study. Planning sophstication impacted on alignment indirectly and the relationship was mediated by shared domain knowledge.

\section{Gains from the strategic aligntnent}

In most strategic fit tudies in strategic management research, business performance is usually used as the criterion to test the effect of alignment. There is no exception in IS strategic fit research. Perceived business performance is often used by many researchers (Teo and King, 1996; Chan et al. 1997; Palmer and Markus, 2000; Sabherwal and Chan, 2001; Chan et al., 2006). For instance, Sabherwal and Chan (2001) measured it with eight items. They are reputation among major customer segments, frequency of new product or service introduction, ROI net profits, technological developments and/or other innovations in business operations, and revenue growth.

With regard to the measurement of business performance, researchers select the measurement according to their different research problems. In investigating the strategic alignment issues in retailing industry, Palmer and Markus (2000) used profitability, comparable store sales growth, sales per employee, sales per square foot, and stoke turns to measure firm performance. The indicators of business performance in Bergeron et al., (2004) were grouped along two dimensions: growth and profitability relative to the competitors.

Instead of business performance, some researchers used IT related performance to test the effect of strategic alignment. Reich and Benbasat (2000) had quality of IT, the progressive use of IT, rational innovation, and IT effectiveness in their study. Kearns and Lederer (2004) conceptualized organizational performance as use of IT for competitive advantage. Use of IT for competitive advantage is believed to impact on financial performance directly and used as 
a proxy for organizational performance. Similarly, Velcu (2010) use the effectiveness of ERP implementation in their study.

\section{Conclusions and future research directions}

Through the review on the conceptualization of IS strategic fit research, we find that there is a weak emphasis on the conceptualization of strategic alignment. Some research even wrongly interpret Venkatraman's (1989) perspectives on fit conceptualization. It is a viable way to use the methodology of fit research in strategic management for reference in IS research. But misunderstanding of the methodology may make later researchers confused and abuse findings from literature. Another issue related to conceptualization of strategic fit in IS research is that only bivariate relationships are used in fit measurement. Although most studies in IS strategic research use multiple dimensions of business strategy or TT strategy, only a few consider multi-dimensions in a holistic view (Johnson and Lederer, 2010). Configuration theory could add more value of strategic fit research in a system view perspective. Contingency theorists endorsed the holistic view of configurational approach in the fit research (Van de Ven and Drazin, 1985). Although Venkatraman (1989) suggested a viable analytical procedure to realize the system view of fit, no typology or taxonomy technique is included to produce an appropriate classification of the sample. Future work on strategic fit in IS research could be done in such a configuration view.

From the framework review of IS strategic fit, we can see that three strategies in IS are included in IS strategic fit research. Few tudies make a clear declaration of difference between IT strategy, IS strategy and IM strategy. No consistent conceptualization and measurement of the three construct are formed. Different terms are used in different studies. Future research should first clearly define and measure the constructs of these strategies in IS. And then future studies could measure their different alignment with business strategy and test their different impact on firmperformance

Structural Contingency Theory has proposed that environment is one of the most important factors that influence the formation of strategy. Many business researches have examined the coalignment between environment and strategy and its impact on firm performance (Hofer, 1975; Hambrick, 1980, Venkatraman and Prescott, 1990). Although the studies that investigate the factors that influence strategic alignment have considered the impact of environment, no researchers have focused on the alignment among environment, business strategy, and IT strategy. It would be a great contribution that researchers investigate how well the business strategy fit the environment, how well the IT strategy fit the business strategy, and how the two kinds of fit influence the firm performance.

In past studies, financial performance is used to investigate the strategic alignment issues in most cases. On the other hand, the IT related performance is seldom used. It is beneficial to accumulative theory development of strategic alignment issues in IS research for the results from these research could justify the alignment effect in the same direction. However, it may be more Interesting to introduce IT related performance measurement in IS strategic fit research. It would enrich our knowledge from different perspective. Sethi and King (1994) develop a performance measure for competitive advantage provided by information technology application. The five dimensions identified in this study could be used for future IS strategic fit research as dependent variables. 


\section{References}

[1] L. Aversano, C. Grasso and M. Tortorella, "A literature review of business/IT alignment strategies", Procedia Technology, vol. 5, (2012), pp. 462-474.

[2] D. Avison, J. Jones, P. Powell and D. Wilson, "Using and validating the strategic alignment model", Journal of Information Systems, vol. 13, (2004), pp. 223-246.

[3] F. Bergeron, L. Raymond and S. Rivard, "Ideal patterns of strategic alignment and business performance", Information and Management, vol. 41, pp. 1003-1020.

[4] A. S. Bharadwaj, "A resource-based perspective on information technology capability and firm performance: an empirical investigation", MIS Quarterly, vol. 24, no. 1, (2000), pp. 169-196.

[5] E. Brynjolfsson, "The Productivity Paradox of Information Technology", Communications of the ACM, vol. 36, no. 12, (1993), pp. 66-77.

[6] E. Brynjolfsson and L. Hitt, "Beyond the Productivity Paradox", Communications of the ACM, vol. 41, no. 8, (1998), pp. 49-55.

[7] L. Chen, "Business-IT alignment maturity of companies in China", Information \& Management, vol. 47, (2010), pp. 9-16.

[8] Y. E. Chen, R. Sabherwal and J. B. Thatcher, "Antecedents and outcomes of strategic IS alignment: an empirical investigation”, IEEE Transaction on Engineering Management vol. 53, no. 1, (2006), pp. 27-47.

[9] R. Chen, C. Sun, M. M. Helms and W. Jih, "Aligning information technolôgy and bustness strategy with a dynamic capabilities perspective: A longitudinal study of Taiwanese Semiconductor company", International Journal of Information Management, vol. 28, (2008), pp. 366-378

[10] Y. Chan, S. Huff, D. W. Barclay and D. G. Copeland, "Busines Strategic Qrientation, Information Systems Strategic Orientation, and Strategic Alignment", Information Systems Research, vol. 8, no. 2, (1997), pp. 125-150.

[11] Y. Chan, R. Sabherwal and J. B. Thatcher, "Antecedents and outcomes of strategic IS alignment: An empirical investigation", IEEE Transaction on Engineering Management, vol. 53. 110. 1, (2006), pp. 27-47.

[12] A. Das and R. Narasimhan, "Process-technology fit and its inmplications for manufacturing performance", Journal of Operations Management, vol. 19, 2001), pp. 521-540

[13] S. R. Das, S. A. Zahra and M. E. Warketin, "Integrating the content and concept of strategic planning with competitive strategy", Decision Sciences vol. 22, (1991), pp. 953-984.

[14] S. Devaraj, D. G. Hollingworth and R. G. Schroeder, "Generic manufacturing strategies and plant performance", Journal of Operations Management, vol.22, (2004), pp. 313-333.

[15] R. Drazin and A. H. Van de Ven, «Alternative forms of fit in contingency theory", Administrative Science Quarterly, vol. 30, (1985), pp 514-539.

[16] M. J. Earl, "Managemen strategies for information technology", Prentice Hall, New York, (1989).

[17] D. C. Hambrick, "Operationalizing the concept of business-level strategy in research", Academy of Management Review, vol. 5, (1980) pp. 567-575.

[18] R. Hayes and S. Wheelwright, "Link manufacturing process and product life cycles", Harvard Business Review, vol. 57, no. 1, (1979) pp.133-140.

[19] J. C. Henderson and N Venkatraman, "Strategic alignment: leveraging information technology for transforming organizations", IBM Systmes Journal, vol. 32, no. 1, (1993), pp. 4-16.

[20] T. Hill and R. Duke-Woolley, "Progression or regression in facilities focus", Strategic Management Journal, vol. 4, (1983), pp. 09-121.

[21] C. F. Ho, "Information technology implementation strategies for manufacturing organizations: a strategic alignment approach”, International Journal of Operations \& Production Management, vol. 16, no. 7, (1996), pp. 77-92.

[22] C. W. Hofer, "Towards a contingency theory of business strategy", Academy of Management Journal, vol. 18, (1975) pp $784-810$.

[23] Kvar), "The Organizational Fit of Information Systems", Journal of I nformation Systems, vol. 2, no. 1, (1992), pp. 3-29.

[24] A. M. Johnson and A. L. Lederer, "CEO/CIO mutual understanding, strategic alignment, and the contribution of IS to the organization”, Information \& Management, vol. 47, (2010), pp. 138-149.

[25] S. Jorfi and H. Jorfi, "Strategic operations management: Investigating the factors impacting IT-business strategic alignment”, Procedia Social and Behavioral Sciences, vol. 24, (2011), pp. 1606-1614.

[26] G. S. Kearns and A. L. Lederer, "The impact of industry contextual factors on IT focus and the use of IT for competitive advantage", Information \& Management, vol. 41, (2004), pp. 899-919.

[27] R. R. Lawrence and J. Lorsch, "Organization and environment", Harvard Graduate School of Business Administration, Boston, MA, (1967).

[28] J. N. Luftman, R. Papp and T. Brier, "Enablers and inhibitors of business-It alignment", Communications of the AIS, vol. 11, no. 1, (1999). 
[29] Y. Merali, T. Papadopoulos and T. Nadkarni, “Information systems strategy: Past, present, future?”, Journal of Strategic Information Systems, vol. 21, (2012), pp. 125-153.

[30] A. D. Meyer, A. S. Tsui and C. R. Hinings, "Configurational approaches to organizational analysis", Academy of Management Journal, vol. 36, no. 6, (1993), pp. 1175-1195.

[31] R. R. Miles and C. C. Snow, "Organizational strategy, structure, and process", McGraw-Hill, New York, (1978).

[32] D. Miller, "Environmental fit versus internal fit", Organization Science, vol. 3, (1992), pp. 159-178.

[33] J. W. Palmer and M. L. Markus, "The performance impacts of quick response and strategic alignment in specialty retailing", Information Systems Research, vol. 11, no. 3, (2000), pp. 241-259.

[34] S. Qrunfleh and M. Tarafdar, "Supply chain information systems strategy: Impacts on supply chain performance and firm performance", International Journal of Production Economics, (2013), In press.

[35] T. Ravichandran and C. Lertwongsatien, "Effect of information systems resources and capabilities on firm performance: a resource-based perspective", Journal of Management Information System, vol. 21, no. 4, (2005), pp. 237-276.

[36] B. H. Reich and I. Benbasat, "Measuring the linkage between business and information technology objectives", MIS Quarterly, vol. 20, no. 1, (1996), pp. 55-81.

[37] B. H. Reich and I. Benbasat, "Factors that influence the social dimension of alignment between business and information technology objectives", MIS Quarterly, vol. 24, no. 1, (2000), pp. 81-113.

[38] R. Sabherwal and P. Kirs, "The Alignment between Organizational Critical Success Factors and information Technology Capability in Academic Institutions”, Decision Sciences, vol 25, no. 2, (1994), pp. 301-330.

[39] R. Sabherwal and Y. E. Chan, "Alignment between business and IS strategies: A study of prospectors, analyzers, and defenders", Information Systems Research, yol. 12, no. 1, (2001), pp. 11-33.

[40] R. Sabherwal, R. Hirschheim and T. Goles, "The dynamics of alignment: insights from a punctuated equilibrium model”, Organization Science, vol. 12, no. 2, (2001), pp. 179-197.

[41] A. H. Segars and V. Grover, "Strategic information nsstems planning success: an investigation of the construct and its measurement", MIS Quarterly, (1998), pp. 139-163.

[42] R. Schmenner, "Every factory has a life cycle", Harvard Business Review, vol. 61, no. 2, (1983), pp. 121-129.

[43] A. Sen and A. P. Sinha, "IT alignment strategies for customer relationship management", vol. 51, (2011), pp. 609-619.

[44] V. Sethi and W. R. King, "Development of measures to assess the extent to which an information technology application provides competitive advantage", Management Seience, vol. 40, no. 12, (1994), pp. 1601-1627.

[45] G. Silveira, "Market priorities, manufacturing configuation, and business performance: an empirical analysis of the order-winners framework", Joumal of Operations Management, vol. 23, (2005), pp. 662-675.

[46] W. Skinner, "Manufacturing missing link in corporate strategy", Harvard Business Review, vol. 47, no. 3, (1969), pp. 136-145.

[47] W. Skinner, "The focusêd factory", Harvard Business Review, vol. 51, no. 3, (1974), pp. 113-121.

[48] H. Tavakolian, "Linking the information technology structure with organizational competitive strategy: a survey", MIS Quarterly, vol. 13, no. 3, (1989), pp. 309-317.

[49] T. Teo and W. R. King, "Assessing the impact of integrating business planning and IS planning", Information \& Management, yol. 30, (1996), pp. 309-321.

[50] T. Teo and J. Ang, "Critical success factors in the alignment of IS plans with business plans", International Journal of Information Management, vol. 19, (1998), pp. 173-185.

[51] A. H. Van de Ven and R Drazin, "The concept of fit in contingency theory", In Barry M. Staw and L.L. Cummings, (eds), Research in Oraganizational Behavior, vol. 7, (1985), pp. 333-365, Greenwich, CT, JAI Press.

[52] O. Velcu, “\$trategic alignment of ERP implementation stages: An empirical investigation”, Information \& Management voll. 47, (2010), pp. 158-166.

[53] N. Verkatraman, "The concept of fit in strategy research: toward verbal and statistical corresponsence", Academy of Management Review, vol. 14, no. 3, (1989), pp. 423-444.

[54] Nenkatraman and J. Prescott, "Environment-strategy coalignment: an empirical test of its performance implications", Strategic Management Journal, vol. 11, no. 1, (1990), pp. 1-23.

[55] J. M. Ward, "Information system strategy: Quo vadis?", Journal of Strategic Information Systems, vol. 21, (2012), pp. 165-171.

[56] T. J. Wong, S. Ngan, F. Chan and A. Y. Chong, "A two-stage analysis of the influences of employee alignment on effecting business-IT alignment”, Decision Support Systems, vol. 53, (2012), pp. 490-498. 


\section{Appendix}

Table 1. Summary of IS related constructs measurement

\begin{tabular}{|c|c|c|}
\hline Author & Construct name & Dimensions \\
\hline Tavakolian (1989) & IT structure & $\begin{array}{ll} & \text { Centralized structure } \\
- & \text { Decentralized structure } \\
\end{array}$ \\
\hline Das et al. (1991) & IT strategy & $\begin{array}{ll} & \text { Competencies } \\
- & \text { Role of IT } \\
\bullet & \text { System design and development } \\
\bullet & \text { Infrastructure }\end{array}$ \\
\hline $\begin{array}{ll}\text { Henerson } & \text { and } \\
\text { Venkatraman (1993) }\end{array}$ & $\begin{array}{l}\text { External IT strategy } \\
\text { Internal IT strategy }\end{array}$ & $\begin{array}{ll}- & \text { Information technology scope (external) } \\
- & \text { Systemic competencies (external) } \\
\text { - } & \text { IT governance (external) } \\
\text { - } & \text { IS architecture (internal) } \\
\text { - } & \text { IS processes (internal) } \\
- & \text { IS skills (internal) } \\
\end{array}$ \\
\hline Ho (1996) & $\begin{array}{l}\text { Structure of IT strategy } \\
\text { Infrastructure of IT } \\
\text { strategy }\end{array}$ & $\begin{array}{ll}\text { - } & \text { System comptencies (strueture) } \\
\text { - } & \text { Technology scope (structure) } \\
\text { - } & \text { IT alliance (structure) } \\
\text { - } & \text { IT-architecture (infrastructure) } \\
\text { - } & \text { Processes (infrastructure) } \\
\text { - } & \text { Skills (infrastructure) } \\
\end{array}$ \\
\hline Chen et al. (1997) & IS structure & $\begin{array}{l}\text { Centralized structure } \\
\text { Decentralized structure } \\
\text { Shared management of IS }\end{array}$ \\
\hline $\begin{array}{l}\text { Palmer and Markus } \\
(2000)\end{array}$ & IS strategy & $\begin{array}{l}\text { Supplien partnering } \\
\text { Transaction efficiency } \\
\text { Customer detail }\end{array}$ \\
\hline Sabherwal et al. (2001) & & $\begin{array}{ll} & \text { Low cost } \\
\text { Differentiation } \\
\text { Growth } \\
\text { Alliance } \\
\text { Innovation } \\
\text { Nonstrategic }\end{array}$ \\
\hline $\begin{array}{l}\text { Sabherwal } \\
(2001)\end{array}$ & & $\begin{array}{ll} & \text { IS for efficiency } \\
- & \text { IS for flexibility } \\
- & \text { IS for comprehensiveness }\end{array}$ \\
\hline Bergeron et al. (2004) & T strategy & $\begin{array}{ll} & \text { IT environment scanning } \\
- & \text { Strategic use of IT }\end{array}$ \\
\hline Bergeron et al. (2004 & IT structure & $\begin{array}{ll}\text { - } & \text { IT organizational architecture } \\
\text { - } & \text { Technological architecture } \\
\text { - } & \text { Process and skill } \\
\end{array}$ \\
\hline Chan et al (2006) & IS strategy & $\begin{array}{ll} & \text { IS for efficiency } \\
\bullet & \text { IS for flexibility } \\
\bullet & \text { IS for comprehensiveness } \\
\end{array}$ \\
\hline $\begin{array}{l}\text { Qnufieh and Tarafdar } \\
(2013)\end{array}$ & IS strategy & $\begin{array}{ll} & \text { IS for efficiency } \\
- & \text { IS for flexibility } \\
\end{array}$ \\
\hline
\end{tabular}


Table 2. Summary of antecedents of strategic fit in IS research

\begin{tabular}{|c|c|}
\hline Author & Factors \\
\hline Teo and Ang (1999) & $\begin{array}{l}\text { Top management commitment to the use of IT } \\
\text { IS management knowledge about business } \\
\text { - Top management confidence in the IS department }\end{array}$ \\
\hline Luftman et al. (1999) & $\begin{array}{ll}\text { - } & \text { Senior executive support for IT } \\
\text { - } & \text { IT's involvement in strategy development } \\
\text { - } & \text { IT's understanding the business } \\
\text { - } & \text { Business-IT partnership } \\
\text { - } & \text { Well-prioritized IT projects } \\
\text { IT's demonstration of leadership }\end{array}$ \\
\hline Reich and Benbasat (2000) & $\begin{array}{l}\text { - Shared domain knowledge between business and IT executives } \\
\text { IT implementation success } \\
\text { - } \\
\text { - Communication between business and IT executives } \\
\text { Connections between business and IT planning processes }\end{array}$ \\
\hline Chan et al. (2006) & $\begin{array}{ll} & \text { Shared domain knowledge } \\
- & \text { Planning sophistication } \\
- & \text { Prior IS success } \\
- & \text { Organizational size } \\
- & \text { Environmental uncertainty }\end{array}$ \\
\hline Chen (2010) & $\begin{array}{ll} & \text { Communication maturity } \\
\text { - } & \text { Competence/value measurement maturity } \\
\text { - } & \text { Governance maturity } \\
\text { - Technology scope maturity } \\
\text { - Skils maturity }\end{array}$ \\
\hline Jorfi and Jorfi(2011) & $\begin{array}{l}\text { IT flexibility } \\
\text { IT capability } \\
\text { Communications effectiveness }\end{array}$ \\
\hline Wong et al. (2012) & $\begin{array}{l}\text { Employee trust } \\
\text { Employee commitment } \\
\text { Employee communication } \\
\text { Employee knowledge }\end{array}$ \\
\hline
\end{tabular}

